Article

\title{
Functionalized $N$-Pyridinylmethyl Engrafted Bisarylmethylidenepyridinones as Anticancer Agents
}

\author{
Dhaifallah M. Al-thamili, Abdulrahman I. Almansour, Natarajan Arumugam $\mathbb{D}$, \\ Faruq Mohammad $D$ and Raju Suresh Kumar*D \\ Department of Chemistry, College of Science, King Saud University, P.O. Box 2455, Riyadh 11451, Saudi Arabia; \\ daife54321@hotmail.com (D.M.A.-t.); almansor@ksu.edu.sa (A.I.A.); anatarajan@ksu.edu.sa (N.A.); \\ farooqm1983@gmail.com (F.M.) \\ * Correspondence: sraju@ksu.edu.sa or drrajusureshkumar@gmail.com
}

Received: 25 July 2020; Accepted: 11 September 2020; Published: 15 September 2020

check for updates

\begin{abstract}
Structurally interesting N-pyridinylmethyl engrafted bisarylmethylidenepyridinones with high functionality have been constructed in good yield. The structural interpretation of these compounds has been done with the aid of spectroscopic analysis and further established by single crystal X-ray diffraction studies. Following physical characterization, the synthesized compounds were tested for their in vitro anticancer activity against HepG2 cancer cells and it was found that all of the compounds exhibited some level of activity. We observed a significant level of cell viability losses to the cancer cells, while only smaller losses to the non-cancer cells were observed. Besides, the mechanistic investigation of toxicology revealed that the cancer cells were undergoing apoptotic pathway, induced by the generation of oxidative stress and the involvement of caspases. The analysis provides preliminary evidence for the successful control of cancer cells with a minimal effect on healthy normal cells because of the high $\mathrm{IC}_{50}$ levels and cell death mechanisms.
\end{abstract}

Keywords: functionalized unsaturated ketones; anticancer studies; apoptosis; caspase-3; ROS generation

\section{Introduction}

Cancer is caused by a series of events, such as the abnormal growth of tumor cells, distortion of normal tissue functions, and migration of mutated cells to different sites of the body in the later stages. The migration of diseased cells to distant sites, called metastasis, is an almost uncontrollable stage of cancer phase as it may become difficult to control the growth of mutated cells in tissues which are deep inside the body [1]. Despite the enormous progress achieved in cancer treatment methodologies through the development of new diagnosis tools and the involvement of anticancer drugs, the treatment process still suffers from the limitations of poor efficacy, non-targeting ability, drug resistance, association with side effects, etc. [2]. Hence, it is highly important to fully understand already available drugs' therapeutic efficacies and invent new drugs with improved efficacy against cancer diseased cells and reduced side effects towards healthy cells.

Compounds owning $\alpha, \beta$-unsaturated carbonyl units are the fundamental core of numerous compounds exhibiting attractive biological properties [3-6]. Since $\alpha, \beta$-unsaturated ketones possess some privileged electrophilic behaviors towards thiol groups as compared to those of amino or hydroxyl groups $[7,8]$, they maintain some resistance from the attacking of nucleic acids with no thiol functionality, and thus the mutagenic and carcinogenic potential of these compounds are observed to be low [9]. In addition, there have been a number of studies that deal with the cytotoxic activities of $\alpha, \beta$-unsaturated ketones which are being designed as thiol-alkylators [10-12]. In one study, for example, acyclic $\alpha, \beta$-unsaturated ketones were found to be nearly bereft of cytotoxic activity following 
their tests against P388 lymphocytic leukemia in mice [13-15]. Later studies dealt with the cytotoxic activity of 2,6-bis(phenylmethylene)-cyclohexanone against murine P388/MRI leukemic cells where the $\mathrm{IC}_{50}$ value disclosed to be $36.5 \mathrm{nM}$ [16]. Some $\mathrm{N}$-unsubstituted 3,5-bis(arylidene)-4-piperidones and $N$-acyl-3,5-bis(benzylidene)-4-piperidones resembled the compounds of the present study and exhibited $\mathrm{IC}_{50}$ values (concentration required to observe $50 \%$ cell death) in the low micromolar to submicromolar range towards a number of malignant cell lines $[17,18]$. Among these compounds, $\mathrm{N}$-acyl analogues exhibited superior cytotoxic activity than their $\mathrm{N}$-unsubstituted analogues towards the P388/MRI cells [16]. Based on the analysis of these compounds' behavior towards the cells, the hepatic glutathione concentrations were observed to be low in mice, thereby providing evidence for their mechanistic action as a thiol alkylator.

In some studies, it has been observed that compounds maintaining two or more alkylation sites possessed more selective toxicity against neoplastic cells as compared to healthy normal cells [19]. The observation of such activity against neoplastic cells can be attributed to the increased chemical insult offered by the presence of more alkylation sites, making the neoplasms more sensitive during a second or third attack [20,21]. Additionally, some other studies have revealed the dependency of enhanced tumor sensitivity with respect to antineoplastic drugs by the potentiators, and so compounds with two or more thiolation sites are of utmost importance in cancer therapy [22-24]. In addition, some studies on piperidone derivatives indicated that compounds with a higher number of unsaturated groups can offer greater potency because of their steric impedance, hence the thiol attack might be weaker as compared to that of a compound with low or no unsaturated groups. Besides, it is noteworthy to mention that substituted piperidine moiety is an integral part of many natural products and a few drugs. In addition, these compounds maintain fluorescent properties along with an antitumor capacity, which can be specifically beneficial to tumor cell studies, thereby making them potential fluorescent antitumor drug candidates [7]. Taking these facts into consideration, developing a series of cancer cell-targeting compounds seems to be judicious; in that view, the current study dealt with the efficient synthesis of targeted pyridinone analogues enclosing $\alpha, \beta$-unsaturated ketone structural motifs as they can attack the thiol groups of nucleic acids better than amino or hydroxy groups. Further, the antiproliferative activity of the synthesized compounds was assessed against two different cell lines: HepG2 161 and L929 cells. Finally, the mechanism of toxicity against the cancer cells was performed with assays of apoptosis, oxidative stress, and by the involvement of caspases.

\section{Materials and Methods}

\subsection{Chemistry}

All reagents and solvents used in the present study were procured from commercial suppliers. The reaction progress was observed by thin layer chromatography (TLC) analysis. The melting points of the synthesized compounds were measured using open capillary tubes and were uncorrected. FT-IR spectra of these compounds were documented on a PerkinElmer system 2000 FT-IR instrument (KBr). A Jeol $500 \mathrm{MHz}$ instrument was employed to measure the NMR spectra of the synthesized compounds while a DART-ToF-MS mass spectrometer was used to record the molecular mass. X-ray data sets of the representative compounds were collected from a STOE IPDS 2 Diffractometer, and structure refinement was done using SHELXL2018/3 (Sheldrick, 2018) Program(s).

\subsection{General Procedure for the Synthesis of N-Pyridinylmethyl-Bisarylmethylidenepyridinones 5(a-h)}

To $20 \mathrm{~mL}$ of acetonitrile, $\mathrm{N}$-unsubstituted pyridinones $3(1 \mathrm{mmol})$ and $\mathrm{K}_{2} \mathrm{CO}_{3}(3 \mathrm{mmol})$ were added and stirred at ambient temperature for $30 \mathrm{~min}$, followed by the gradual addition of pyridine hydrochloride $4(1.1 \mathrm{mmol})$, and then the whole reaction mixture was allowed to reflux. After the complete disappearance of the starting materials, as evidenced by the TLC analysis, the reaction mixture was allowed to cool to room temperature. The filtrate collected after filtration was evaporated, and the residue partitioned between $20 \mathrm{~mL}$ of $\mathrm{CHCl}_{3}$ and $10 \mathrm{~mL}$ of water. The organic phase was 
separated, dried $\left(\mathrm{Na}_{2} \mathrm{SO}_{4}\right)$, and evaporated. Crystallization of the crude product in acetonitrile afforded compound 5 in pure form.

2.2.1. N-1-(2-Pyridinylmethyl)-3,5-bis[(E)-Phenylmethylidene]Tetrahydro-4(1H)-Pyridinone (5a)

Obtained as yellow solid, $(1.76 \mathrm{~g}, 88 \%) ; \mathrm{mp}=85-88^{\circ} \mathrm{C}$; IR (KBr): 1671, 1612, $1586 \mathrm{~cm}^{-1} ;{ }^{1} \mathrm{H}$ NMR $\left(500 \mathrm{MHz}, \mathrm{CDCl}_{3}\right): \delta_{\mathrm{H}} 3.87\left(2 \mathrm{H}, \mathrm{s}, 7^{\prime}-\mathrm{CH}_{2}\right), 3.92-3.93\left(4 \mathrm{H}, \mathrm{m}, 2^{\prime}-\mathrm{CH}_{2}\right.$ and $\left.6^{\prime}-\mathrm{CH}_{2}\right), 7.08-7.11(1 \mathrm{H}, \mathrm{m}$, ArH), 7.33-7.38 (11H, m, ArH), 7.50-7.54 (1H, m, ArH), 7.81 (2H, s, ArH), 8.48-8.50 (1H, m, ArH). ${ }^{13} \mathrm{C}$ NMR $\left(125 \mathrm{MHz}, \mathrm{CDCl}_{3}\right): \delta_{\mathrm{C}} 54.89,63.21,122.27,122.98,128.53,128.97,130.37,133.21,135.15,136.52$, 136.60, 149.12, 157.79, 187.54. Mass: $367\left[\mathrm{M}^{+}\right]$. Anal. calcd for $\mathrm{C}_{25} \mathrm{H}_{22} \mathrm{~N}_{2} \mathrm{O}: \mathrm{C}, 81.94 ; \mathrm{H}, 6.05 ; \mathrm{N}, 7.64 \%$; found: $\mathrm{C}, 81.82 ; \mathrm{H}, 6.23 ; \mathrm{N}, 7.75 \%$.

2.2.2. N-1-(2-Pyridinylmethyl)-3,5-bis[(E)-(2-Methylphenyl)Methylidene]Tetrahydro-4(1H)Pyridinone $(5 \mathbf{b})$

Obtained as yellow solid, (1.8 g, 90\%); mp $=96-98^{\circ} \mathrm{C}$; IR (KBr): 1672, 1615, $1589 \mathrm{~cm}^{-1} ;{ }^{1} \mathrm{H}$ NMR $\left(500 \mathrm{MHz}, \mathrm{CDCl}_{3}\right): \delta_{\mathrm{H}} 2.34\left(6 \mathrm{H}, \mathrm{s}, \mathrm{CH}_{3}\right), 3.73-3.75\left(6 \mathrm{H}, \mathrm{m}, 2-\mathrm{CH}_{2^{\prime}}, 6-\mathrm{CH}_{2^{\prime}}\right.$ and $\left.7^{\prime}-\mathrm{CH}_{2}\right), 7.05-7.25$ $(10 \mathrm{H}, \mathrm{m}, \mathrm{ArH}), 7.47-7.50(1 \mathrm{H}, \mathrm{m}, \mathrm{ArH}), 7.97(2 \mathrm{H}, \mathrm{s}, \mathrm{ArH}), 8.42-8.43(1 \mathrm{H}, \mathrm{m}, \mathrm{ArH}) .{ }^{13} \mathrm{C}$ NMR $(125 \mathrm{MHz}$, $\left.\mathrm{CDCl}_{3}\right): \delta_{\mathrm{C}} 20.02,54.58,62.78,122.15,122.94,125.50,128.78,130.24,133.35,134.20,136.16,136.38,138.05$, 149.13, 157.74, 187.41. Mass: $395\left[\mathrm{M}^{+}\right]$. Anal. calcd for $\mathrm{C}_{27} \mathrm{H}_{26} \mathrm{~N}_{2} \mathrm{O}: \mathrm{C}, 82.20 ; \mathrm{H}, 6.64 ; \mathrm{N}, 7.10 \%$; found: C, $82.33 ; \mathrm{H}, 6.49 ; \mathrm{N}, 7.31 \%$.

2.2.3. N-1-(2-Pyridinylmethyl)-3,5-bis[(E)-(2-Methoxylphenyl)Methylidene]Tetrahydro-4(1H)Pyridinone (5c)

Obtained as yellow solid, yield $=85 \% ; \mathrm{mp}=120-122{ }^{\circ} \mathrm{C}$; IR $(\mathrm{KBr}): 1670,1614,1586 \mathrm{~cm}^{-1} ;{ }^{1} \mathrm{H}$ NMR $\left(500 \mathrm{MHz}, \mathrm{CDCl}_{3}\right): \delta_{\mathrm{H}} 3.78\left(3 \mathrm{H}, \mathrm{s}, \mathrm{OCH}_{3}\right), 3.81\left(3 \mathrm{H}, \mathrm{s}, \mathrm{OCH}_{3}\right), 3.82-3.83\left(6 \mathrm{H}, \mathrm{m}, 2^{\prime}-\mathrm{CH}_{2}, 6-\mathrm{CH}_{2^{\prime}}\right.$ and $\left.7^{\prime}-\mathrm{CH}_{2}\right), 6.86-6.90(4 \mathrm{H}, \mathrm{m}, \mathrm{ArH}), 7.02-7.12(3 \mathrm{H}, \mathrm{m}, \mathrm{ArH}), 7.23-7.29(3 \mathrm{H}, \mathrm{m}, \mathrm{ArH}), 7.43-7.46(1 \mathrm{H}, \mathrm{m}$, $\mathrm{ArH}), 8.06(2 \mathrm{H}, \mathrm{s}, \mathrm{ArH}), 8.44-8.45(1 \mathrm{H}, \mathrm{m}, \mathrm{ArH}) .{ }^{13} \mathrm{C} \mathrm{NMR}\left(125 \mathrm{MHz}, \mathrm{CDCl}_{3}\right): \delta_{\mathrm{C}} 54.60,55.19,62.35$, 110.37, 119.75, 121.78, 122.68, 124.06, 129.94, 130.11, 132.26, 132.90, 136.120, 148.80, 157.89, 158.08, 187.34. Mass: $427\left[\mathrm{M}^{+}\right]$. Anal. calcd for $\mathrm{C}_{27} \mathrm{H}_{26} \mathrm{~N}_{2} \mathrm{O}_{3}: \mathrm{C}, 76.03 ; \mathrm{H}, 6.14 ; \mathrm{N}, 6.57 \%$; found: $\mathrm{C}, 76.24 ; \mathrm{H}, 6.02 ; \mathrm{N}$, $6.70 \%$.

2.2.4. N-1-(2-Pyridinylmethyl)-3,5-bis[(E)-(3-Nitrophenyl)Methylidene]Tetrahydro-4(1H)Pyridinone (5d)

Obtained as yellow solid, $(1.70 \mathrm{~g}, 85 \%) ; \mathrm{mp}=158-160{ }^{\circ} \mathrm{C}$; IR $(\mathrm{KBr}): 1668,1615,1589 \mathrm{~cm}^{-1} ;{ }^{1} \mathrm{H}$ NMR $\left(500 \mathrm{MHz}, \mathrm{CDCl}_{3}\right): \delta_{\mathrm{H}} 3.88\left(2 \mathrm{H}, \mathrm{s}, 7^{\prime}-\mathrm{CH}_{2}\right), 3.91-3.92\left(4 \mathrm{H}, \mathrm{m}, 2^{\prime}-\mathrm{CH}_{2}\right.$ and $\left.6^{\prime}-\mathrm{CH}_{2}\right), 7.10-7.12(1 \mathrm{H}$, $\mathrm{m}, \mathrm{ArH}), 7.29(1 \mathrm{H}, \mathrm{d}, \mathrm{J}=7.5 \mathrm{~Hz}, \mathrm{ArH}), 7.55-7.65(6 \mathrm{H}, \mathrm{m}, \mathrm{ArH}), 7.80(2 \mathrm{H}, \mathrm{s}, \mathrm{ArH}), 8.17-8.19(3 \mathrm{H}, \mathrm{m}$, $\mathrm{ArH}), 8.48-8.50(1 \mathrm{H}, \mathrm{m}, \mathrm{ArH}) .{ }^{13} \mathrm{C} \mathrm{NMR}\left(125 \mathrm{MHz}, \mathrm{CDCl}_{3}\right): \delta_{\mathrm{C}} 54.40,63.13,123.35,123.67,124.53$, 129.76, 134.20, 135.26, 135.96, 136.61, 136.81, 148.42, 149.51, 156.92, 186.52. Mass: 457 [M+ ${ }^{+}$. Anal. calcd for $\mathrm{C}_{25} \mathrm{H}_{20} \mathrm{~N}_{4} \mathrm{O}_{5}: \mathrm{C}, 65.78 ; \mathrm{H}, 4.42 ; \mathrm{N}, 12.27 \%$; found: $\mathrm{C}, \mathrm{C}, 65.91 ; \mathrm{H}, 4.59 ; \mathrm{N}, 12.15 \%$.

2.2.5. N-1-(2-Pyridinylmethyl)-3,5-bis[(E)-(4-Methylphenyl)Methylidene]Tetrahydro-4(1H)Pyridinone (5e)

Obtained as yellow solid, (1.80 g, 90\%); mp $=130-133{ }^{\circ} \mathrm{C}$; IR (KBr): 1670, 1618, $1586 \mathrm{~cm}^{-1} ;{ }^{1} \mathrm{H}$ NMR $\left(500 \mathrm{MHz}, \mathrm{CDCl}_{3}\right): \delta_{\mathrm{H}} 2.35\left(6 \mathrm{H}, \mathrm{s}, \mathrm{CH}_{3}\right), 3.87\left(2 \mathrm{H}, \mathrm{s}, 7^{\prime}-\mathrm{CH}_{2}\right), 3.90-3.91\left(4 \mathrm{H}, \mathrm{m}, 2^{\prime}-\mathrm{CH}_{2}\right.$ and $\left.6^{\prime}-\mathrm{CH}_{2}\right), 7.08-7.10(1 \mathrm{H}, \mathrm{m}, \mathrm{ArH}), 7.16-7.18(3 \mathrm{H}, \mathrm{m}, \mathrm{ArH}), 7.24-7.26(5 \mathrm{H}, \mathrm{m}, \mathrm{ArH}), 7.31(1 \mathrm{H}, \mathrm{d}, \mathrm{J}=7.5 \mathrm{~Hz}$, $\mathrm{ArH}), 7.50-7.53(1 \mathrm{H}, \mathrm{m}, \mathrm{ArH}), 7.77(2 \mathrm{H}, \mathrm{s}, \mathrm{ArH}), 8.48-8.50(1 \mathrm{H}, \mathrm{m}, \mathrm{ArH}) .{ }^{13} \mathrm{C} \mathrm{NMR}\left(125 \mathrm{MHz}, \mathrm{CDCl}_{3}\right)$ : $\delta_{C} 21.39,55.01,63.28,122.25,122.99,129.30,130.50,132.38,136.43,136.64,139.30,149.10,158.51,187.53$. Mass: $395\left[\mathrm{M}^{+}\right]$. Anal. calcd for $\mathrm{C}_{27} \mathrm{H}_{26} \mathrm{~N}_{2} \mathrm{O}: \mathrm{C}, 82.20 ; \mathrm{H}, 6.64 ; \mathrm{N}, 7.10 \%$; found: $\mathrm{C}, 82.35 ; \mathrm{H}, 6.76 ; \mathrm{N}$, $7.02 \%$. 
2.2.6. N-1-(2-Pyridinylmethyl)-3,5-Bis[(E)-(4-Chlorophenyl)Methylidene]Tetrahydro-4(1H)Pyridinone (5f)

Obtained as yellow solid, $(1.76 \mathrm{~g}, 88 \%) ; \mathrm{mp}=129-131^{\circ} \mathrm{C}$; IR (KBr): 1671, 1617, $1587 \mathrm{~cm}^{-1} ;{ }^{1} \mathrm{H}$ NMR $\left(500 \mathrm{MHz}, \mathrm{CDCl}_{3}\right): \delta_{\mathrm{H}} 3.84-3.88\left(6 \mathrm{H}, \mathrm{m}, 2^{\prime}-\mathrm{CH}_{2}, 6^{\prime}-\mathrm{CH}_{2}\right.$ and $\left.7^{\prime}-\mathrm{CH}_{2}\right), 7.11-7.13(1 \mathrm{H}, \mathrm{m}, \mathrm{ArH})$, 7.25-7.35 (9H, m, ArH), 7.53-7.56 (1H, m, ArH), 7.72 (2H, s, ArH), 8.48-8.50 (1H, m, ArH). ${ }^{13} \mathrm{C}$ NMR $\left(125 \mathrm{MHz}, \mathrm{CDCl}_{3}\right): \delta_{\mathrm{C}} 54.73,63.20,122.44,123.03,128.85,131.55,133.49,135.11,135.31,136.70,149.20$, 157.51, 187.06. Mass: $436\left[\mathrm{M}^{+}\right]$. Anal. calcd for $\mathrm{C}_{25} \mathrm{H}_{20} \mathrm{Cl}_{2} \mathrm{~N}_{2} \mathrm{O}: \mathrm{C}, 68.97 ; \mathrm{H}, 4.63 ; \mathrm{N}, 6.43 \%$; found: $\mathrm{C}$, $68.81 ; \mathrm{H}, 4.51 ; \mathrm{N}, 6.62 \%$.

2.2.7. N-1-(2-Pyridinylmethyl)-3,5-Bis[(E)-(4-Fluorophenyl)Methylidene]Tetrahydro-4(1H)- Pyridinone $(5 \mathrm{~g})$

Obtained as yellow solid, yield $=88 \% ; \mathrm{mp}=110-112{ }^{\circ} \mathrm{C}$; IR $(\mathrm{KBr}): 1668,1615,1588 \mathrm{~cm}^{-1} ;{ }^{1} \mathrm{H}$ NMR $\left(500 \mathrm{MHz}, \mathrm{CDCl}_{3}\right): \delta_{\mathrm{H}} 3.84-3.87\left(6 \mathrm{H}, \mathrm{m}, 2^{\prime}-\mathrm{CH}_{2}, 6^{\prime}-\mathrm{CH}_{2}\right.$ and $\left.7^{\prime}-\mathrm{CH}_{2}\right), 7.03-7.11(5 \mathrm{H}, \mathrm{m}, \mathrm{ArH})$, 7.28-7.33 (5H, m, ArH), 7.51-7.54 (1H, m, ArH), 7.74 (2H, s, ArH), 8.48-8.49 (1H, m, ArH). ${ }^{13} \mathrm{C}$ NMR $\left(125 \mathrm{MHz}, \mathrm{CDCl}_{3}\right): \delta_{\mathrm{C}} 54.73,63.23,115.60,115.78,122.35,122.99,131.23,131.24,132.30,132.77,135.36$, 136.62, 149.16, 157.62, 161.86, 163.86, 187.19. Mass: 403 [M $\mathrm{M}^{+}$. Anal. calcd for $\mathrm{C}_{25} \mathrm{H}_{20} \mathrm{~F}_{2} \mathrm{~N}_{2} \mathrm{O}: \mathrm{C}, 74.61$; $\mathrm{H}, 5.01 ; \mathrm{N}, 6.96 \%$; found: $\mathrm{C}, 74.77 ; \mathrm{H}, 5.14 ; \mathrm{N}, 6.85 \%$.

2.2.8. N-1-(2-Pyridinylmethyl)-3,5-Bis[(E)-(2,4-Dichlorophenyl)Methylidene]Tetrahydro-4(1H)Pyridinone (5h)

Obtained as yellow solid, (1.80 g, 90\%); mp $=105-107^{\circ} \mathrm{C}$; IR (KBr): 1672, 1615, $1584 \mathrm{~cm}^{-1} ;{ }^{1} \mathrm{H}$ NMR $\left(500 \mathrm{MHz}, \mathrm{CDCl}_{3}\right): \delta_{\mathrm{H}} 3.71-3.76\left(4 \mathrm{H}, \mathrm{m}, 2^{\prime}-\mathrm{CH}_{2}\right.$ and $\left.6^{\prime}-\mathrm{CH}_{2}\right), 3.95\left(2 \mathrm{H}, \mathrm{s}, 7^{\prime}-\mathrm{CH}_{2}\right), 7.05-7.25$ (5H, m, ArH), 7.42-7.52 (4H, m, ArH), 7.89 (2H, s, ArH), 8.44-8.45 (1H, m, ArH). ${ }^{13} \mathrm{C}$ NMR $(125 \mathrm{MHz}$, $\left.\mathrm{CDCl}_{3}\right): \delta_{\mathrm{C}} 53.86,62.07,122.08,122.20,126.55,126.58,129.52,130.60,131.66,132.83,134.42,134.45$, 135.56, 136.27, 148.97, 157.09, 186.12. Mass: $505\left[\mathrm{M}^{+}\right]$. Anal. calcd for $\mathrm{C}_{25} \mathrm{H}_{18} \mathrm{Cl}_{4} \mathrm{~N}_{2} \mathrm{O}: \mathrm{C}, 59.55 ; \mathrm{H}, 3.60$; N, 5.56\%; found: C, 59.67; H, 3.49; N, 5.65\%.

\subsection{Biology}

\subsubsection{Cell Culture and Maintenance}

For the testing of the anticancer efficacy of our synthesized compounds, two different cell lines, one cancerous and the other non-cancerous, were selected. The cancer cell lines included HepG2 cells of human hepatic cells, and the selected non-cancer cells were L929 cells of mouse subcutaneous connective tissue, obtained from National Centre for Cell Science (NCCS), Pune, India. Both cell types were cultured individually in Eagle's Minimum Essential Medium (EMEM) supplemented with 10\% fetal bovine serum (FBS) containing the antibiotics streptomycin $(100 \mathrm{U} / \mathrm{mL})$ and penicillin $(100 \mathrm{U} / \mathrm{mL})$. For culturing, the cells were suspended in cell culture flasks and incubated at $37{ }^{\circ} \mathrm{C}$ in a $5 \% \mathrm{CO}_{2}$ humidified atmosphere. The cells were extracted when the growth reached $80 \%$ confluency, and the cell counting was done with the aid of a hemocytometer; the corresponding assays were performed after calculating the cell viability and seeding.

\subsubsection{MTT Cytotoxicity Assay}

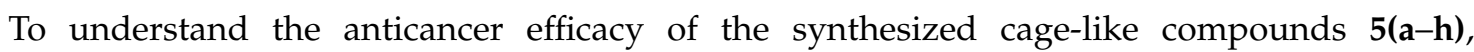
the 3-(4,5-dimethylthiazol-2-yl)-2,5-diphenyltetrazolium bromide (MTT) assay was performed, and was based on the reduction of MTT dye by the cells. The HepG2 cells having the suspension of $2 \times 10^{4}$ cells/well/200 $\mu \mathrm{L}$ of EMEM were added to 96-well plates and allowed to grow for another $12 \mathrm{~h}$. After this period, different concentrations of the test compounds in the range of $0-200 \mu \mathrm{g} / \mathrm{mL}$ were added to the wells and incubated for another $24 \mathrm{~h}$ in a $5 \% \mathrm{CO}_{2}$ atmosphere. Then, the medium was removed, and the fresh medium containing 2\% FBS was added and incubated for another $2 \mathrm{~h}$. After this period, $20 \mu \mathrm{L}\left(5 \mathrm{mg} / \mathrm{mL}\right.$ ) of MTT reagent was added to the cells and incubated in $\mathrm{CO}_{2}$ atmospheric 
air for another $2 \mathrm{~h}$. At the end of incubation, the formazan crystals formed were dissolved in $100 \mu \mathrm{L}$ of dimethylsufoxide (DMSO) and the absorbance was measured at $570 \mathrm{~nm}$ using an ELISA microplate reader. The cells without any testing sample treatment were taken as the negative control with $100 \%$ viability and Melphalan (Mel) of $15 \mu \mathrm{g} / \mathrm{mL}$ concentration was taken as the positive control where the \% (percentage) viability of the cells was determined from the following Equation (1).

$$
\% \text { viability }=\frac{\text { Mean absorbanceof test sample }}{\text { Mean absorbanceof negative control }} \times 100
$$

Similarly, $\mathrm{IC}_{50}$ values were determined for all of the testing samples (the $\mathrm{IC}_{50}$ value for each sample was determined based on the linear regression equation generated from the plot of $\log$ concentration vs. cell viability). From the analysis of the results provided by the MTT assay and $\mathrm{IC}_{50}$ values, the highly effective samples $5(\mathbf{a}, \mathbf{g})$ were determined, and cell viability studies were performed using the non-cancer L929 cell line so as to understand the active samples' behavior towards healthy normal cells.

\subsubsection{Apoptosis Assay}

The apoptotic assay was carried out on the HepG2 cells using the testing sample of $5 \mathrm{~g}$, for which the Annexin V/FITC kit (BD Biosciences; Catalog no. 556547) was employed. For the assay, the cells at a density of $1 \times 10^{6}$ cells/well were plated and allowed to settle for $12 \mathrm{~h}$, and after the period, the wells were treated with $\mathrm{IC}_{50}$ concentrations of the testing compound $(5 \mathrm{~g})$ and the positive control of Mel and incubated for another $24 \mathrm{~h}$. The flow cytometric analysis was used to estimate the fluorescence intensities generated by the cells due to the involvement of FITC-conjugated Annexin V and PI (propidium iodide) dyes. For the analysis, the samples of treated cells were collected, washed with a PBS buffer, and resuspended in Annexin V-FITC buffer. The suspension was incubated at $25^{\circ} \mathrm{C}$ for $10 \mathrm{~min}$ in the dark with $5 \mu \mathrm{L}$ of Annexin V-FITC (provided by the manufacturer). Then, the cell pellet was collected using centrifugation and suspended again in an Annexin V-FITC buffer, and $5 \mu \mathrm{L}$ of PI was added in an ice bath and further analyzed on a flow cytometry instrument that operates on a Cell Quest software (Becton Dickinson Biosciences). Each experiment was repeated thrice for accuracy and the average of each individual fluorescence experiment was taken as the final where the data shown are the mean $\pm \mathrm{SD}(n=3)$.

\subsubsection{Oxidative Stress Assay}

The generation of oxidative stress due to the treatment of compound $\mathbf{5 g}$ in the HepG2 cells was studied by analyzing the reactive oxygen species (ROS) formation. For the testing, the cells at a density of $1 \times 10^{5}$ cells/well were first seeded in 6-well plates, allowed to adhere, and when the cell growth reached its $80 \%$ confluence, they were treated with the $\mathrm{IC}_{50}$ values of the testing compounds $(5 \mathrm{~g}$ and $\mathrm{Mel}$ ), and incubated for another $24 \mathrm{~h}$. After this period, the medium was removed, and the cells were washed with D-PBS twice and incubated with $10 \mu \mathrm{M}$ of H2DFCDA (provided by the manufacturer, Invitrogen, catalog number: D399) in a dark condition at room temperature for $30 \mathrm{~min}$. All of the assay protocols were followed as indicated by the manufacturer, i.e., washing of the cultured cells with D-PBS twice, pellet collection using centrifugation, resuspension of the obtained pellet in $500 \mu \mathrm{L}$ of D-PBS, and further analysis of the cells by BD FACS Calibur. The compound $5 \mathbf{g}$ results were compared with those of Mel and the cells of without any treatment.

\subsubsection{Caspase-3 Expression Assay}

Similar to the earlier assays, the HepG2 cells at density of $1 \times 10^{5}$ cells/well were seeded in 6-well culturing plates, allowed to grow for $12 \mathrm{~h}$, treated with respective test compounds, and allowed to incubate for $24 \mathrm{~h}$. After the incubation period, all steps were followed in accordance with the manufacturer's instruction, i.e., removal of the medium, washing of the cells with D-PBS twice, 
and fixing of the cells with $2 \%$ paraformaldehyde. The cells were then permeabilized with $0.01 \%$ Tween 20 in D-PBS and, having 1\% bovine serum albumin (BSA), incubated with $50 \mu \mathrm{L}$ of Caspase 3-FITC (Abcam, ab65613) in the dark at room temperature for another $60 \mathrm{~min}$. Finally, the cells were washed, suspended in a PBS solution, and analyzed for the expression of caspases by an EVOS FL AUTO fluorescence microscope.

\subsubsection{Statistical Analysis}

Each sample was tested thrice for the accuracy of its biological efficacy, and the average of all of the obtained values was considered as final, where the data shown are the mean \pm SD. The statistical analysis was based on the Student's t-test, and, from the analysis, the significant values $(p<0.05)$ are shown by * and the highly significant values $(p<0.01)$ are shown as ${ }^{*}$ against the untreated control measurements run using the GraphPad prism software (version 6).

\section{Results and Discussion}

\subsection{Chemistry}

In the contemporary work, we envisioned synthesizing the target compounds 5(a-h) from the reaction of 3,5-bis[ $(E)$-arylmethylidene]tetrahydro-4(1H)-pyridinones $\mathbf{3 ( a - h )}$ and 2-(chloromethyl)pyridine hydrochloride 4 (Scheme 1). The synthesis of the prerequisite compounds 3(a-h) was performed based on a literature method reported by Dimmock et al. [17]. Primarily, in order to determine the optimum reaction conditions, a typical reaction comprising an equimolar ratio of $3 \mathrm{c}$ and 4 was performed in diverse organic solvents, viz. dioxane, methanol, acetonitrile, ethanol, chloroform, and dimethylformamide (DMF). Among the solvents employed, acetonitrile was found be optimal for this transformation in terms of reaction time and yield. The target compound, viz. the $\alpha, \beta$-unsaturated carbonyl compound $5 c$, was obtained in good yield. Similarly, the other reactions with diversely substituted aryl rings $\mathbf{3}(\mathbf{a}, \mathbf{b})$ and $\mathbf{3}(\mathbf{d}-\mathbf{h})$ were also accomplished under these optimized reaction conditions and a good yield of the products $\mathbf{5}(\mathbf{a}, \mathbf{b})$ and $\mathbf{5}(\mathbf{d}-\mathbf{h})$ was obtained. The structure of the target compounds $\mathbf{5}(\mathbf{a}-\mathbf{h})$ was derived through IR, NMR spectroscopy, and mass spectrometry data. Furthermore, the stereochemistry of these compounds was determined by single crystal X-ray crystallographic studies of 5c (Figure 1) [25].

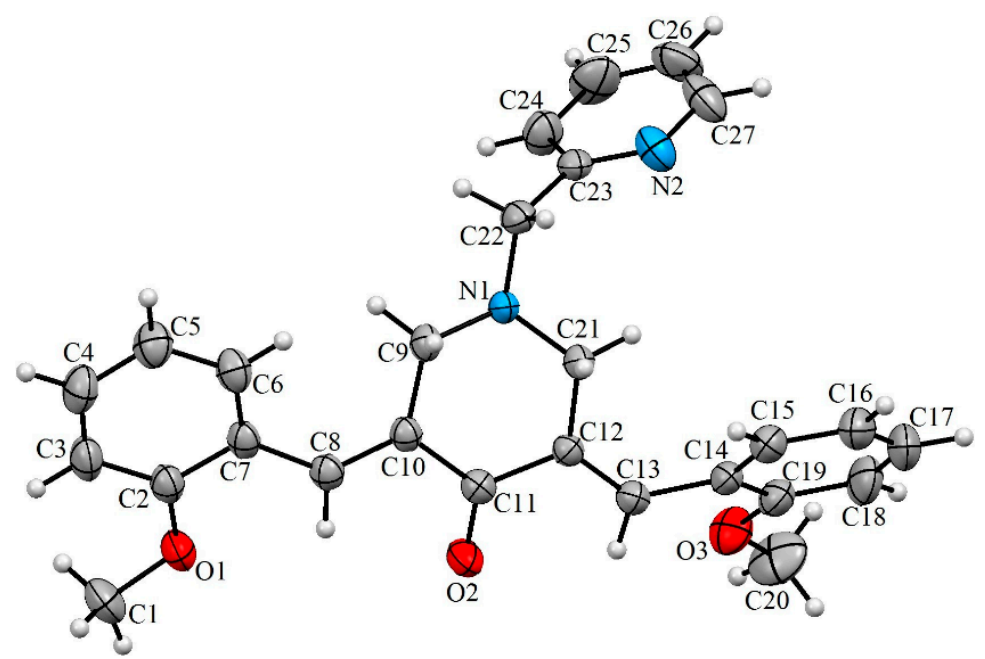

Figure 1. Oak Ridge Thermal Ellipsoid Plot (ORTEP) diagram of 5c. 

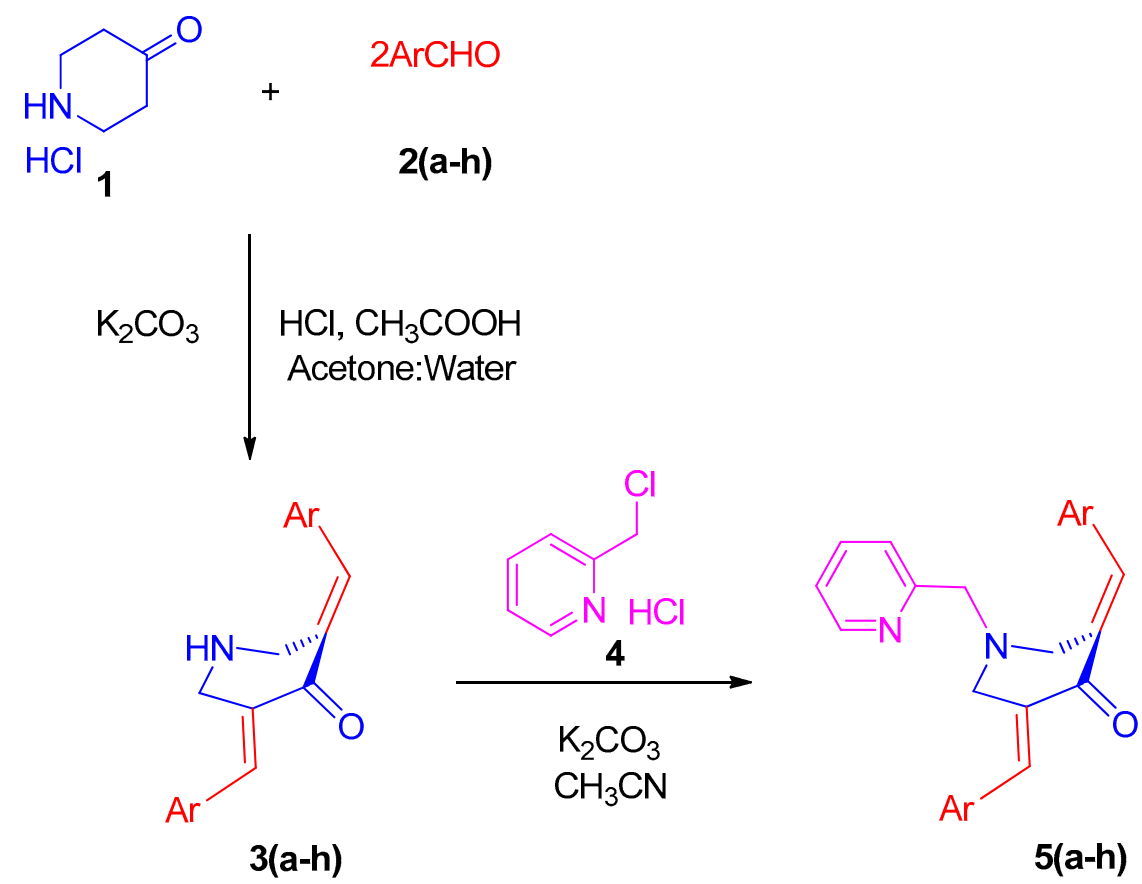

Scheme 1. Synthesis model employed for the formation of $N$-pyridinylmethylbisarylmethylidenepyridinones $5(\mathbf{a}-\mathbf{h})$.

\subsection{Biology}

The in vitro cell viability studies of the HepG2 cancer cells, following the treatment of testing compounds $5(\mathbf{a}-\mathbf{h})$ at a $12.5-200 \mu \mathrm{g} / \mathrm{mL}$ concentration over a $24 \mathrm{~h}$ period, are shown in Figure 2. Upon treatment with the synthesized derivatives, it was found that all of the compounds were exhibiting some level of anticancer activity against the cancer cells and that this activity was increasing with concentration increases when we compared it with the positive control of Mel $(15 \mu \mathrm{g} / \mathrm{mL})$ and the negative control of no treatment. The cell viability data revealed that the highest activity was witnessed for $\mathbf{5 g}$ and the least for compound $\mathbf{5 c}$. The $\mathrm{IC}_{50}$ values obtained for all of the tested compounds after the $24 \mathrm{~h}$ incubation period are shown in Table 1 , and, based on these, the anticancer activity followed the order of $\mathbf{5 g}>\mathbf{5 a}>\mathbf{5 h}>\mathbf{5 d}>\mathbf{5 f}>\mathbf{5 b}>\mathbf{5 e}>\mathbf{5 c}$. In a similar way to the HepG2 cancer cells, the two highly active compounds from the series, viz. $\mathbf{5 a}$ and $\mathbf{5 g}$, were tested against the L929 non-cancer cells over the same $24 \mathrm{~h}$ time period and in the concentration range of $12.5-200 \mu \mathrm{g} / \mathrm{mL}$ (Figure 3). Table 1 also shows the $\mathrm{IC}_{50}$ values of the tested compounds, $\mathbf{5 a}$ and $\mathbf{5 g}$, against $\mathrm{L} 929$ cells over a $24 \mathrm{~h}$ period. From the analysis of the $\mathrm{IC}_{50}$ data provided (Table 1 ), it is clear that a very high concentration of the testing compound (about $47.96 \mu \mathrm{g} / \mathrm{mL}$ for $5 \mathrm{a}$ and $67.25 \mathrm{for} 5 \mathrm{~g}$ ) was required in order to achieve a $50 \%$ cell viability loss towards the non-cancer cells (L929). However, only a small concentration was enough for the same $50 \%$ viability losses towards the cancer cells (HepG2), i.e., about $23.5 \mu \mathrm{g} / \mathrm{mL}$ for $5 \mathrm{a}$ and $12.06 \mu \mathrm{g} / \mathrm{mL}$ for $5 \mathrm{~g}$. In that way, one can say that the tested compounds were not acting very aggressively against the non-cancer cells, and this means that when we use any of the two compounds $\mathbf{5}(\mathbf{a}, \mathbf{g})$ for the anticancer activity, a reduction in the cancer cell viability can be achieved with minimal or negligible loss to the healthy and non-cancer cells. Also, the improved anticancer activity of $\mathbf{5}(\mathbf{a}, \mathbf{g})$ derivatives against the other compounds from the same series may be attributed to the greater solubility and polarity of the respective compounds in the culturing medium and associated interaction of the testing compounds with cells. 


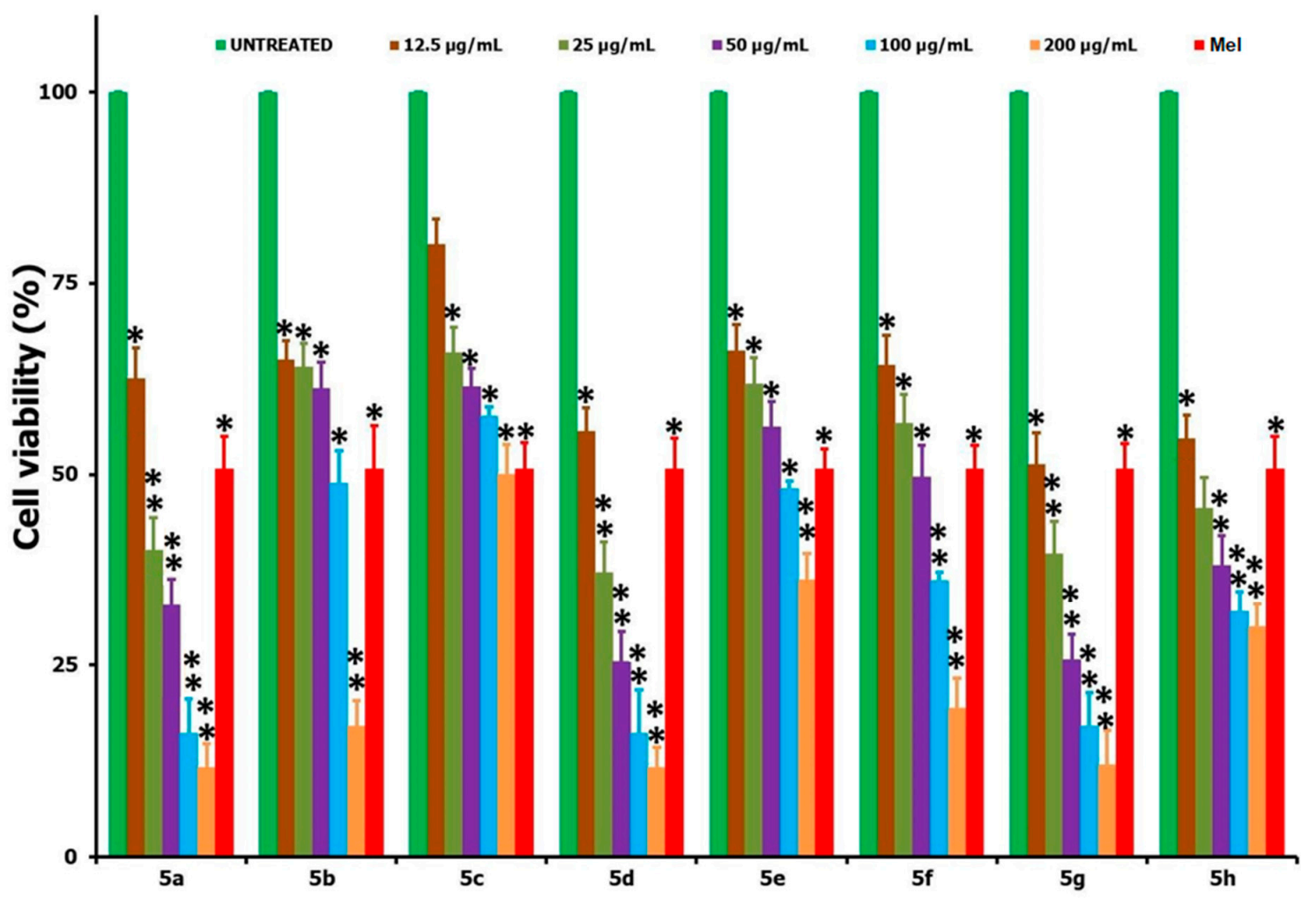

Figure 2. Comparison of the in vitro cell viability studies provided by the MTT assay when the HepG2 cancer cells were treated with compounds $\mathbf{5}(\mathbf{a}-\mathbf{h})$ at different concentrations in the range of 12.5-200 $\mu \mathrm{g} / \mathrm{mL}$ for a $24 \mathrm{~h}$ period. STD corresponds to Melphalan (Mel) $(15 \mu \mathrm{g} / \mathrm{mL}) ;{ }^{*}$ and ${ }^{* *}$ correspond to the significant $(p<0.05)$ and highly significant $(p<0.01)$ values, respectively, against the untreated controlled measurements.

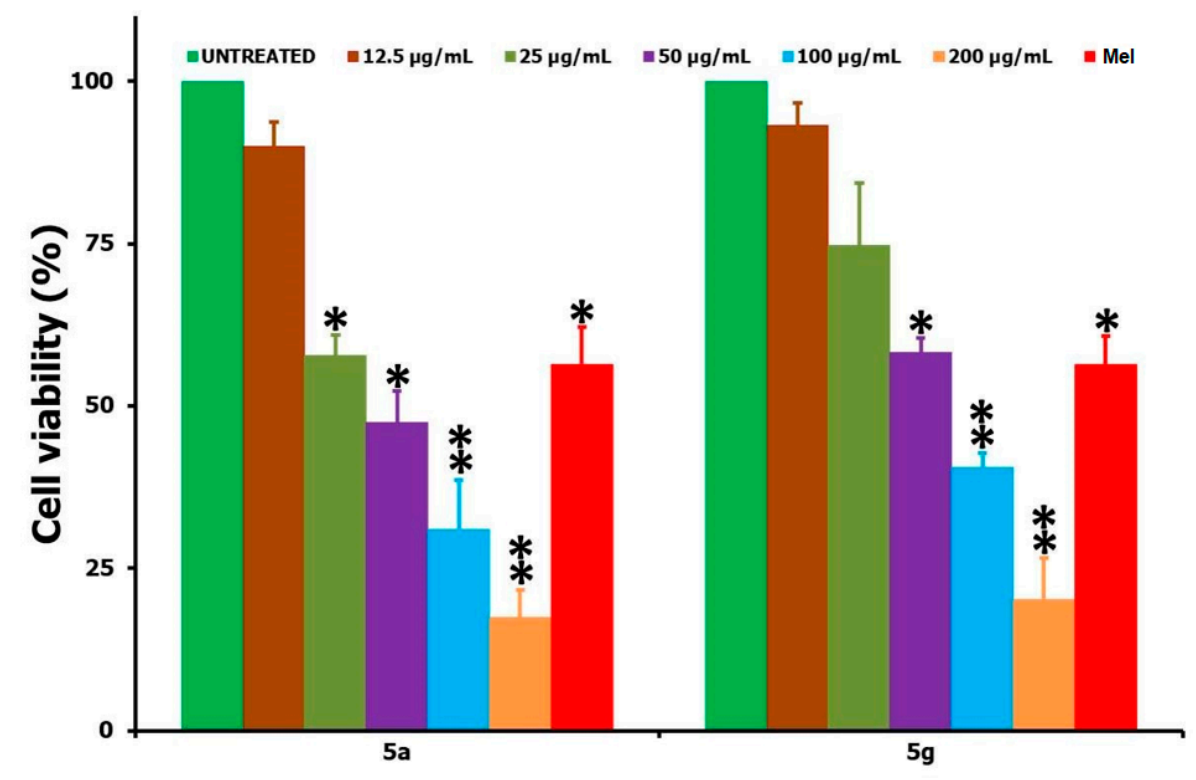

Figure 3. Comparison of the in vitro cell viability studies provided by the MTT assay when the L929 non-cancer cells were treated with $5 \mathbf{a}$ and $\mathbf{5 g}$ at different concentrations in the range of $12.5-200 \mu \mathrm{g} / \mathrm{mL}$ for a $24 \mathrm{~h}$ period. STD corresponds to $\mathrm{Mel}(15 \mu \mathrm{g} / \mathrm{mL}){ }^{*}{ }^{*}$ and ${ }^{* *}$ correspond to the significant $(p<0.05)$ and highly significant $(p<0.01)$ values, respectively, against the untreated controlled measurements. 
Table 1. Comparison of the $\mathrm{IC}_{50}$ values of compounds $\mathbf{5}(\mathbf{a}-\mathbf{h})$ against HepG2 cancer cells over a $24 \mathrm{~h}$ period.

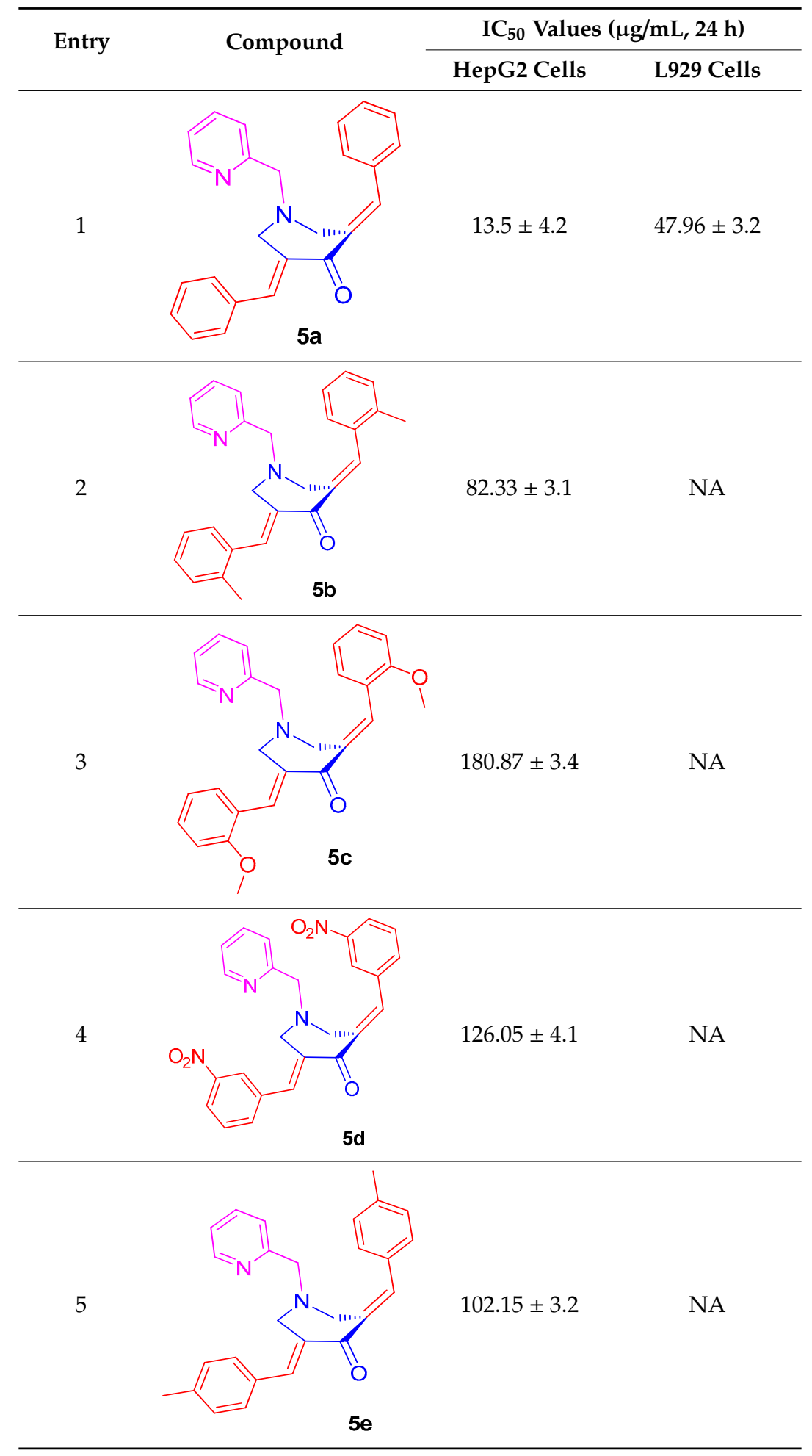


Table 1. Cont.

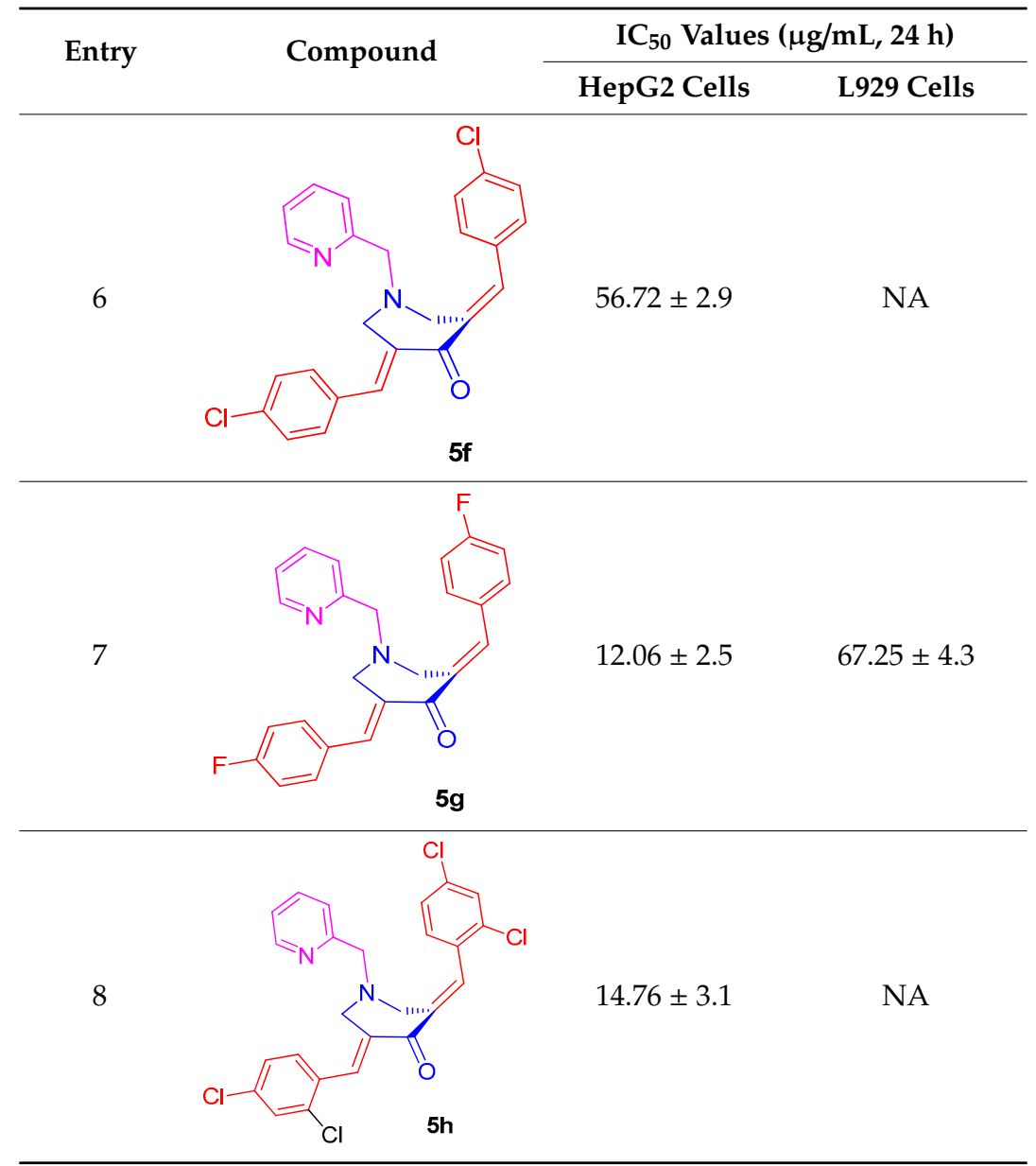

Following the in vitro cell viability assay against the cancer and non-cancer cells, the highly active compound $5 \mathrm{~g}$ at its $\mathrm{IC}_{50}$ concentration of $12 \mu \mathrm{g} / \mathrm{mL}$ was investigated for the mechanism of cell death against the cancer cells. For this, various assays, such as apoptosis, oxidative stress, and caspases, were performed. Figure 4 shows the comparison of the apoptosis assay results of the compound $\mathbf{5 g}$ with those of Mel $(15 \mu \mathrm{g} / \mathrm{mL})$ and of the cells without any treatment over a $24 \mathrm{~h}$ period; the analysis of the results shown in Figure 4 of A-1, B-1, and C-1 corresponds to the mixed fluorescence intensities from Annexin V-fluorescein isothiocyanate (Annexin V-FITC) and propidium iodide (PI) for the untreated, Mel, and $5 \mathrm{~g}$ treated cells, respectively. We observed that the compound $5 \mathrm{~g}$ treated cells were acting somewhat better than the positive control Mel in terms of producing only $2.5 \%$ of necrotic, $49.3 \%$ of apoptotic, and $43.2 \%$ of viable cells (Figure $4(\mathrm{C}-1)$ ) against the $10.3 \%$ of necrotic, $44 \%$ of apoptotic, and $41.8 \%$ viable for Mel (Figure 4(B-1)). Further, the M1 and M2 (shown in A-2, B-2, and C-2) stands for the Annexin V-FITC induced fluorescence intensities from the normal (no significant apoptosis) and apoptotic cells, respectively, and so, from the results shown in Figure 4(C-2), the compound $5 \mathrm{~g}$ treated cells were shown to be producing $62.6 \%$ of cells that were apoptotic. This value of apoptotic cells is high compared to that for Mel, which produced only 54.3\% of apoptotic cells (Figure 4(B-2)), while the untreated cells produced only $1.3 \%$ of cells that were involved in the apoptosis mechanism (Figure 4(A-2)). From the overall analysis of the apoptosis assay results, it can be inferred that the compound $\mathbf{5 g}$ induces cancer cells to take the apoptotic pathway before it may actually lose its viability. 

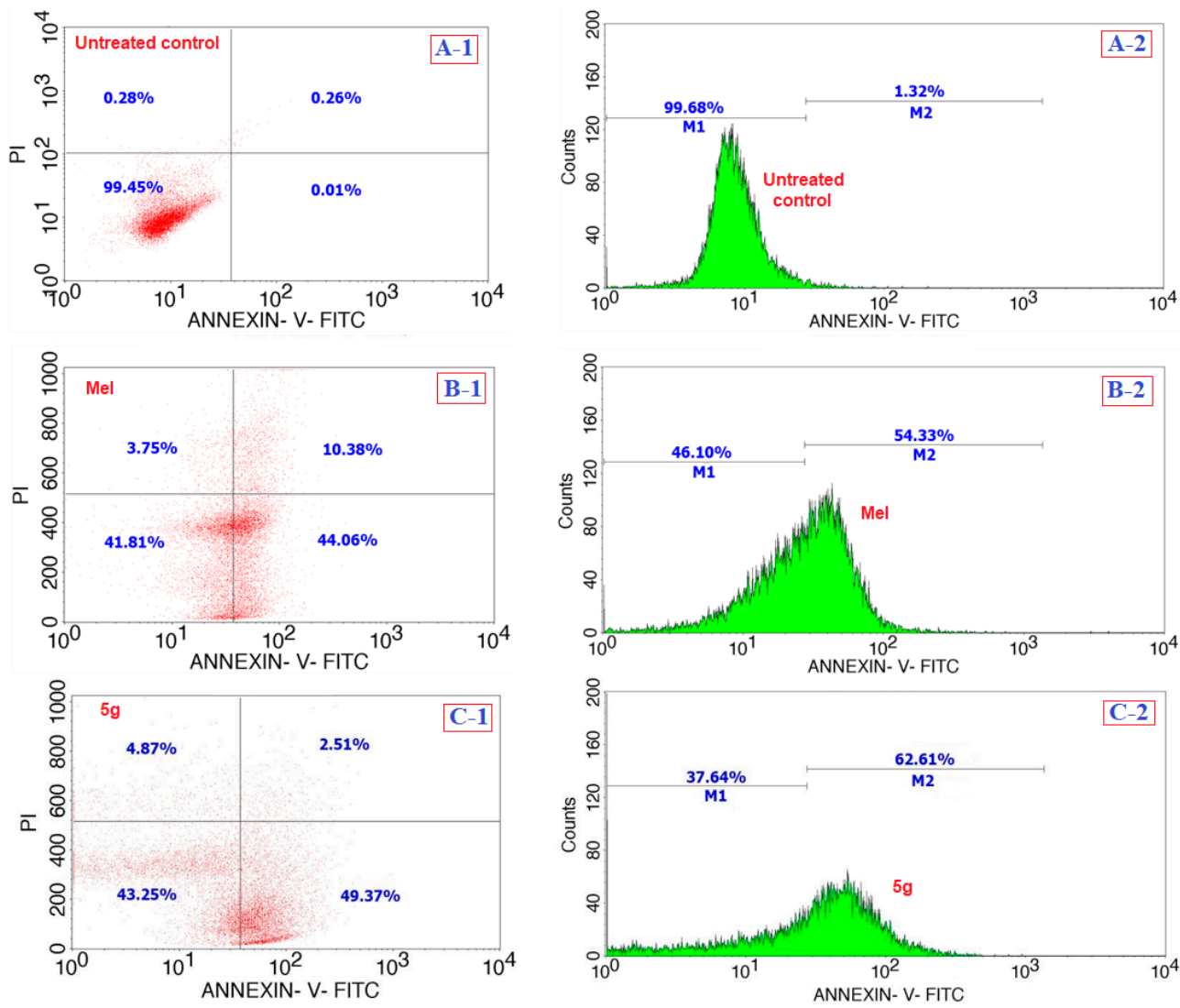

Figure 4. Comparison of the apoptosis assay results of the testing compound $5 \mathrm{~g}(\mathrm{C})$ with those of the positive control $\mathrm{Mel}$ (B), and the negative control of cells without any treatment (A) over a period of $24 \mathrm{~h}$.

Figure 5 shows the flow cytometric analysis of the involvement of ROS following the treatment of $5 \mathrm{~g}($ at $12 \mu \mathrm{g} / \mathrm{mL}$ ) and a comparison with Mel (positive control) and cells with no treatment (negative control), where M1 and M2 correspond to the fluorescence intensities from the normal viable (no significant ROS) and ROS-induced cells (significant), respectively [26]. From the analysis of the results showed in Figure 5(C-2), we found that ROS were generated in about $86.1 \%$ of $\mathbf{5 g}$ treated cells, and this value was higher than the positive control of Mel and the negative control, with only $0.69 \%$ and $0.06 \%$ of cells which could produce ROS, respectively. Further analysis of the caspase- 3 activity in compound 5g treated HepG2 cells were compared for fluorescence intensity with that of the positive control (Mel) and the negative control (no treatment) and the results are shown in Figure 6. From the analysis of the results, we observed that the activity was higher for compound $\mathbf{5 g}$ treated cancer cells as compared to the Mel, providing evidence for the involvement of caspases in cancer cells.

The biological evaluation of the synthesized compounds $\mathbf{5}(\mathbf{a}-\mathbf{h})$ by means of in vitro cytotoxicity analysis indicated that all of the compounds were maintaining some level of anticancer activity against HepG2 cancer cells, and this activity increased when the compound concentration increased. We found that the highest level of activity was recorded for compound $5 \mathrm{~g}$ compared with all of the other compounds, and for that reason, the mechanistic toxicology studies towards the cell deaths were investigated for this particular sample; it was found that the cells were undergoing the apoptotic mechanism induced by the generation of ROS, and cell deaths were increasing through the release of caspases-in particular, caspase-3. Based on this analysis, we can see that the synthesized compounds can be employed to treat cancer cells with minimal damage to non-cancer cells, as very high concentrations are required to cause $50 \%$ of healthy normal cells to lose their viability, while a low concentration is sufficient for the induction of the same effect towards cancer cells; this can be due to the physiological and intracellular responses of cancer cells towards our compound. 

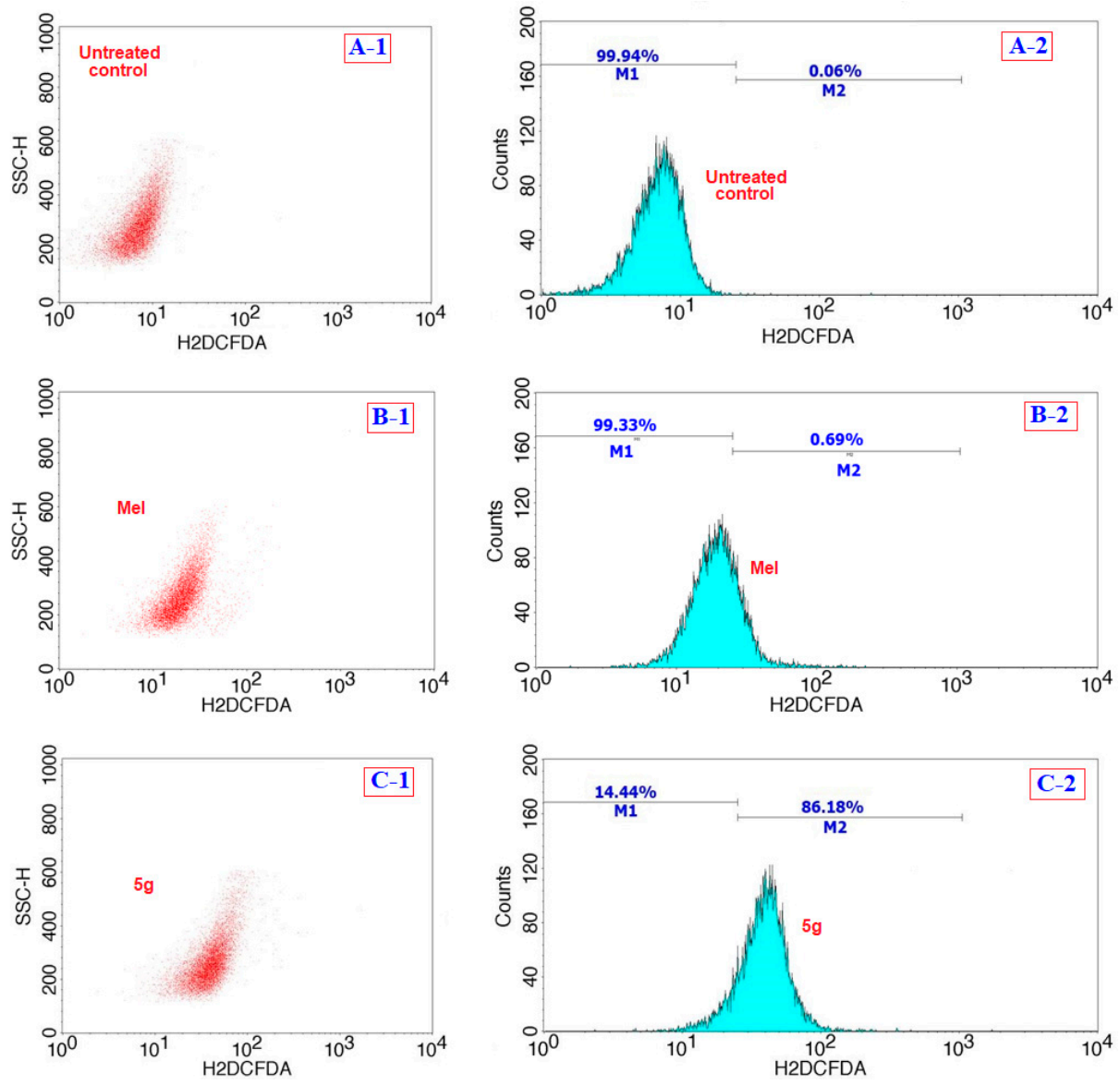

Figure 5. Comparison of flow cytometric analysis of the generation of reactive oxygen species (ROS) in HepG2 cells after treatment with the compound $5 \mathrm{~g}(\mathbf{C})$ with that of the positive control Mel (B), and the negative control of cells without any treatment (A) over a period of $24 \mathrm{~h}$.
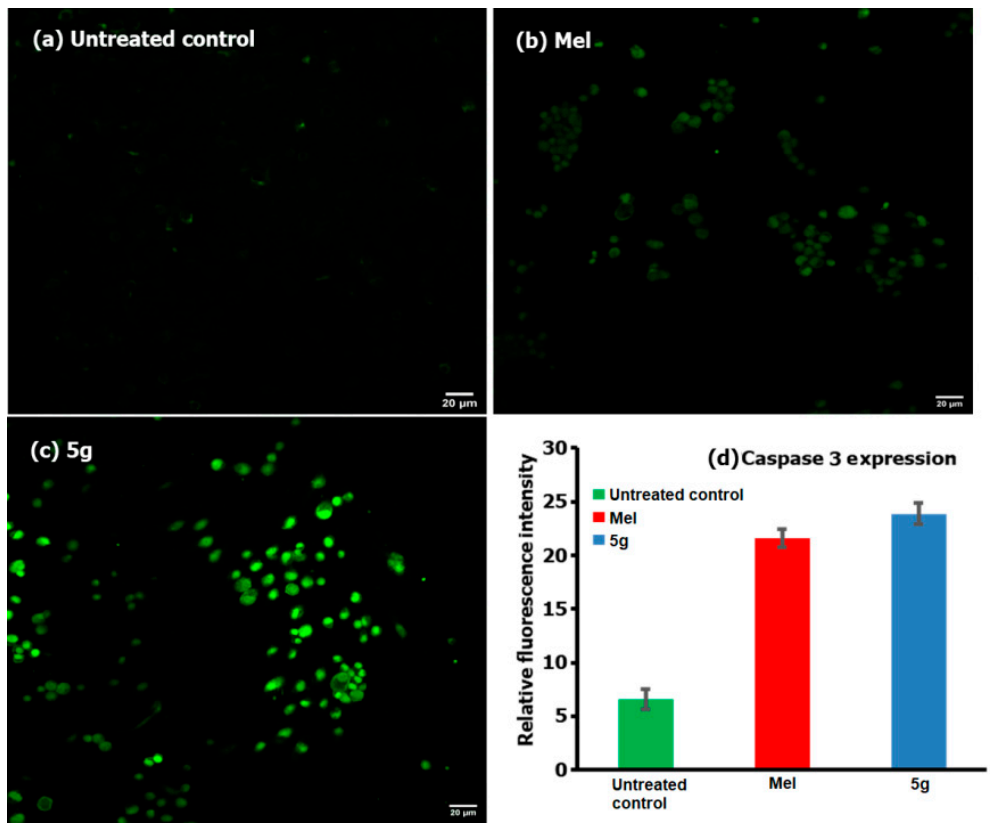

Figure 6. Caspase-3 activity of HepG2 cells when treated against the testing compound $5 \mathbf{g}$ (c) and the positive control of $\mathrm{Mel}(\mathbf{b})$. The cells without any treatment were taken as the negative control (a), and the relative fluorescence intensities are shown in (d). 


\section{Conclusions}

In the present work, some structurally interesting $N$-pyridinylmethyl engrafted bisarylmethylidenepyridinones with high functionality were synthesized with good yield. The structural interpretation of these compounds was done through spectroscopic analysis. Following the physical characterization, the compounds $5(\mathbf{a}-\mathbf{h})$ were tested for their anticancer activities by making use of HepG2 cells up to a $200 \mu \mathrm{g} / \mathrm{mL}$ concentration over a $24 \mathrm{~h}$ period. From the comparative analysis of synthesized compounds against $\mathrm{Mel}(15 \mu \mathrm{g} / \mathrm{mL})$ and cells without any treatment, we observed that most of the derivatives exhibited certain levels of anticancer activity by significantly decreasing the cells' viability. The highest levels of activity against the cancer cells were found to be exhibited by compounds $5 \mathbf{a}, \mathbf{g}$, and with the same compounds, when tested with the non-cancer cells, we observed only limited cell losses, and the $\mathrm{IC}_{50}$ values were found to be relatively very high. On consideration of the structure-activity relationship for the two compounds, the highest level of activity was observed for the one with two fluoro substitutions at the para position (5g), followed by the derivative having no other substitution than that of the naked core (5a). The observation of such activity by the two derivatives can be linked to the solubility in the culturing medium influenced by the polarity, steric hindrance, and associated interaction with the intracellular proteins. Further analysis of the cancer cell deaths showed that the cells were taking the apoptotic pathway, induced by the generation of ROS and through the release of caspases. This analysis provides preliminary evidence for the effective controlling of cancer cells with no or minimal damage to the healthy cells because of the variation of toxicity doses and cell death mechanisms. Finally, the results generated in this work can be used for designing new therapeutic drugs or improving on the traditional drugs by developing a better restriction capacity over the fast growing cancer cells, while simultaneously protecting the moderately proliferating non-cancer cells and thereby paving the way towards sustainable cancer treatment processes.

Author Contributions: Conceptualization, R.S.K.; Writing-original draft preparation and supervision, R.S.K.; Investigation, D.M.A.-t.; Investigation, supervision, and funding acquisition, A.I.A.; Investigation, N.A.; Writing-original draft preparation, F.M. All authors have read and agreed to the published version of the manuscript.

Funding: This research was funded by Deanship of Scientific Research, King Saud University, research group (No. RGP-026).

Acknowledgments: The authors would like to extend their sincere appreciation to the Deanship of Scientific Research at King Saud University, Riyadh, Saudi Arabia for funding this work through the research grant number RGP-026.

Conflicts of Interest: The authors declare no conflict of interest.

\section{References}

1. Harris, C.C. Chemical and physical carcinogenesis: Advances and perspectives for the 1990s. Cancer Res. 1991, 51, 5023-5044.

2. Wong, C.F.; Guminski, A.; Saunders, N.A.; Burgess, A.J. Exploiting novel cell cycle targets in the development of anticancer agents. Curr. Cancer Drug Targets 2005, 5, 85-102. [CrossRef] [PubMed]

3. Lunardi, F.; Guzela, M.; Rodrigues, A.T.; Corrêa, R.; Eger-Mangrich, I.; Steindel, M.; Grisard, E.C.; Assreuy, J.; Calixto, J.B.; Santos, A.R. Trypanocidal and leishmanicidal properties of substitution-containing chalcones. Antimicrob. Agents Chemother. 2003, 47, 1449-1451. [CrossRef] [PubMed]

4. Chimenti, F.; Fioravanti, R.; Bolasco, A.; Chimenti, P.; Secci, D.; Rossi, F.; Yanez, M.; Orallo, F.; Ortuso, F.; Alcaro, S. Chalcones: A Valid Scaffold for Monoamine Oxidases Inhibitors. J. Med. Chem. 2009, 52, 2818-2824. [CrossRef] [PubMed]

5. Zarghi, A.; Zebardast, T.; Hakimion, F.; Shirazi, F.H.; Rao, P.N.; Knaus, E.E. Synthesis and biological evaluation of 1,3-diphenylprop-2-en-1-ones possessing a methanesulfonamido or an azido pharmacophore as cyclooxygenase-1/-2 inhibitors. Bioorg. Med. Chem. 2006, 14, 7044-7050. [CrossRef] 
6. Bag, S.; Ramar, S.; Degani, M.S. Synthesis and biological evaluation of $\alpha, \beta$-unsaturated ketone as potential antifungal agents. Med. Chem. Res. 2009, 18, 309-316. [CrossRef]

7. Das, U.; Pati, H.N.; Sakagami, H.; Hashimoto, K.; Kawase, M.; Balzarini, J.; De Clercq, E.; Dimmock, J.R. 3,5-Bis(benzylidene)-1-[3-(2-hydroxyethylthio)propanoyl]piperidin-4-ones: A novel cluster of potent tumor-selective cytotoxins. J. Med. Chem. 2011, 54, 3445-3449. [CrossRef]

8. Dimmock, J.R.; Kumar, P.; Chen, M.; Quail, J.W.; Yang, J.; Allen, T.M.; Kao, G.Y. Synthesis and cytotoxic evaluation of mesna adducts of some 1-aryl-4,4-dimethyl-5-(1-piperidino)-1-penten-3-one hydrochlorides. Pharmazie 1995, 50, 449-453. [CrossRef]

9. Okey, A.B.; Harper, P.A. Chemical carcinogenesis. In Principles of Medical Pharmacology, 7th ed.; Galant, H., Grant, D.M., Mitchell, J., Eds.; Elsevier: Toronto, ON, Canada, 2007; p. 902.

10. Cheng, C.C. Progress in Medicinal Chemistry, Volume 25; Ellis, G.P., Wesl, G.B., Eds.; Elsevier Science Publishers: Amsterdam, The Netherlands, 1988; pp. 35-83.

11. Dimmock, J.R.; Erciyas, E.; Sidhu, K.K.; Luo, X.; Mezey, P.G.; Allen, T.M.; Murray, L. Charge densities of atoms of conjugated styryl ketones having activity against L1210 leukemia cells. Drug Des Deliv. 1990, 7, 45-49. [PubMed]

12. Dimmock, J.R.; Wong, M.C.L. Bioactivities and potential uses in drug design of acyclic alpha, beta-unsaturated ketones. Can. J. Pharm. Sci. 1976, 11, 35-53.

13. Dimmock, J.R.; Smith, L.M. Syntheses and evaluation of ketals, hemithioketals, and dithioketals of conjugated styryl ketones principally for antineoplastic activity. J. Pharm. Sci. 1980, 69, 575-580. [CrossRef] [PubMed]

14. Dimmock, J.R.; Nyathi, C.B.; Smith, P.J. Syntheses and bioactivities of 1-(hydroxyphenyl)-1-nonen-3-ones and related ethers and esters. J. Pharm. Sci. 1979, 68, 1216-1221. [CrossRef] [PubMed]

15. Dimmock, J.R.; Kirkpatrick, D.L.; Webb, N.G.; Cross, B.M. Synthesis and evaluation of some alkoxy-, chloro-, and acyloxy-conjugated styryl ketones against P-388 lymphocytic leukemia and an examination of the metabolism and toxicological effects of 1-(m-ethoxymethyloxyphenyl)-1-nonen-3-one in rats. J. Pharm. Sci. 1982, 71, 1000-1007. [CrossRef] [PubMed]

16. Dimmock, J.R.; Arora, V.K.; Wonko, S.L.; Hamon, N.W.; Quail, J.W.; Jia, Z.; Warrington, R.C.; Fang, W.D.; Lee, J.S. 3,5-Bis-benzylidene-4-piperidones and related compounds with high activity towards P388 leukemia cells. Drug Des. Deliv. 1990, 6, 183-194.

17. Dimmock, J.R.; Padmanilayam, M.P.; Puthucode, R.N.; Nazarali, A.J.; Motaganahalli, N.L.; Zello, G.A.; Quail, J.W.; Oloo, E.O.; Kraatz, H.B.; Prisciak, J.S.; et al. A conformational and structure-activity relationship study of cytotoxic 3,5-bis(arylidene)-4-piperidones and related N-acryloyl analogues. J. Med. Chem. 2001, 44, 586-593. [CrossRef]

18. Pati, H.N.; Das, U.; Quail, J.W.; Kawase, M.; Sakagami, H.; Dimmock, J.R. Cytotoxic 3,5-bis(benzylidene)piperidin-4-ones and $\mathrm{N}$-acyl analogs displaying selective toxicity for malignant cells. Eur. J. Med. Chem. 2008, 43, 1-7. [CrossRef]

19. Dimmock, J.R.; Kandepu, N.M.; Nazarali, A.J.; Motaganahalli, N.L.; Kowalchuk, T.P.; Pugazhenthi, U.; Prisciak, J.S.; Quail, J.W.; Allen, T.M.; LeClerc, R.; et al. Sequential cytotoxicity: A theory evaluated using novel 2-[4-(3-aryl-2-propenoyloxy)phenylmethylene]cyclohexanones and related compounds. J. Med. Chem. 2000, 43, 3933-3940. [CrossRef]

20. Tsutsui, K.; Komuro, C.; Ono, K.; Nishidai, T.; Shibamoto, Y.; Takahashi, M.; Abe, M. Chemosensitization by buthionine sulfoximine in vivo. Int. J. Radiat. Oncol. Biol. Phys. 1986, 12, 1183-1186. [CrossRef]

21. Mitchell, J.B.; Russo, A. The role of glutathione in radiation and drug induced cytotoxicity. Br. J. Cancer Suppl. 1987, 8, 96-104.

22. Brandes, L.J.; Queen, G.M.; LaBella, F.S. N,N-diethyl-2-[4-(phenylmethyl)phenoxy] ethanamine (DPPE) a chemopotentiating and cytoprotective agent in clinical trials: Interaction with histamine at cytochrome P450 3A4 and other isozymes that metabolize antineoplastic drugs. Cancer Chemother. Pharmacol. 2000, 45, 298-304. [CrossRef]

23. Griffin, R.J.; Arris, C.E.; Bleasdale, C.; Boyle, F.T.; Calvert, A.H.; Curtin, N.J.; Dalby, C.; Kanugula, S.; Lembicz, N.K.; Newell, D.R.; et al. Resistance-modifying agents. 8. Inhibition of O(6)-alkylguanine-DNA alkyltransferase by $\mathrm{O}(6)$-alkenyl-, $\mathrm{O}(6)$-cycloalkenyl-, and $\mathrm{O}(6)-(2-$-oxoalkyl)guanines and potentiation of

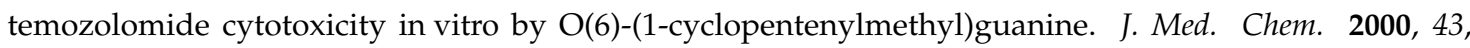
4071-4083. [CrossRef] [PubMed] 
24. Vahrmeijer, A.L.; van Dierendonck, J.H.; Schutrups, J.; van de Velde, C.J.; Mulder, G.J. Potentiation of the cytostatic effect of melphalan on colorectal cancer hepatic metastases by infusion of buthionine sulfoximine (BSO) in the rat: Enhanced tumor glutathione depletion by infusion of BSO in the hepatic artery. Cancer Chemother. Pharmacol. 1999, 44,111-116. [CrossRef] [PubMed]

25. Al-thamili, D.M.; Almansour, A.I.; Arumugam, N.; Kansız, S.; Dege, N.; Soliman, S.M.; Azam, M.; Kumar, R.S. Highly functionalized N-1-(2-pyridinylmethyl)-3,5-bis[(E)-arylmethylidene]tetrahydro-4(1H)-pyridinones: Synthesis, characterization, crystal structure and DFT studies. J. Mol. Struct. 2020, 1222, 128940. [CrossRef]

26. Mishra, T.; Arya, R.K.; Meena, S.; Joshi, P.; Pal, M.; Meena, B.; Upreti, D.K.; Rana, T.S.; Datta, D. Isolation, characterization and anticancer potential of cytotoxic triterpenes from Betula utilis bark. PLOS ONE 2016, 11, e0159430. [CrossRef]

(C) 2020 by the authors. Licensee MDPI, Basel, Switzerland. This article is an open access article distributed under the terms and conditions of the Creative Commons Attribution (CC BY) license (http://creativecommons.org/licenses/by/4.0/). 